\title{
Raciocínio Clínico de Estudantes de Medicina no Ciclo Básico
}

\section{Clinical Reasoning Among Medical Students at the End of the Basic Cycle}

\author{
Gustavo Henrique Bregagnollo \\ Djon Machado Lopes ${ }^{I}$ \\ Bruna Morais Barbosa ${ }^{I I}$ \\ Ana Maria Nunes de Faria Stamm ${ }^{I}$
}

\section{PALAVRAS-CHAVE}

- Diagnóstico.

- Pensamento.

- Estudantes.

- Educação Médica.

Recebido em: 09/09/2016

Aprovado em: 21/10/2016

\section{RESUMO}

Introdução: As estratégias de raciocínio clínico têm como fundamento teórico os modelos hipotético-dedutivo e indutivo. O primeiro se baseia na geração de hipóteses a partir do conhecimento acerca das patologias, e o segundo, em generalizações com base nos dados do caso ou reconhecimento de padrão. O pensamento de um médico ou estudante pode ser avaliado por meio da técnica think aloud (TTA). Objetivos: Identificar as estratégias de raciocínio clínico e a organização e conteúdo do conhecimento de acadêmicos de Medicina na resolução de um caso clínico protótipo em Clínica Médica por meio da aplicação da TTA. Método: Estudo qualitativo realizado com estudantes de graduação em Medicina no final do ciclo básico em uma universidade pública brasileira ao longo de 2014. A partir da teoria dos protótipos e da percepção de 41 alunos sobre sinais, sintomas, síndromes e doenças típicas na Clínica Médica, construiu-se um caso clínico. A TTA foi aplicada individualmente a 30 estudantes, sorteados da amostra inicial, para obter a gravação em áudio da verbalização do processo de raciocínio frente ao caso apresentado. A transcrição das falas permitiu avaliar os textos por análise de conteúdo e identificar os processos de interpretação e combinação, bem como categorizar as estratégias de raciocinio. Foram ainda identificados os eixos semânticos, que foram classificados nas categorias de sintomas, sinais, sindromes, doenças, dados factuais e processos. Resultados: Foram elaboradas 105 hipóteses diagnósticas principais (HDP), de 12 tipos distintos, identificadas como primárias, e 12 como secundárias, com média de 3,5 hipóteses principais por aluno. Na elaboração das HDP, predominou a estratégia Esquema-Indutivo $(E-I)=42,3 \%$, seguida pelo Reconhecimento de Padrão (R-P) $=21,2 \%$, Mista E-I (15,4\%), Mista R-P (10,6\%) e Hipotético-Dedutiva (10,6\%). Quanto a organização e conteúdo do conhecimento, houve média de 12,9 eixos semânticos por aluno, 20,9 processos de interpretação e 6,8 de combinação. Conclusões: A estratégia de raciocínio indutiva é predominante na elaboração de HDP entre acadêmicos de Medicina no final do ciclo básico. Os alunos apresentam uma rede semântica sólida e habilidade nos processos de interpretação, mas reduzida capacidade de associação quando comparados a médicos experientes.
REVISTA BRASILEIRA DE EDUCAÇ̃̃o MÉDICA

$44 \overline{41(1): 4449 ; 2017}$
${ }^{1}$ Universidade Federal de Santa Catarina, Florianópolis, SC, Brasil.

"Iniversidade do Sul de Santa Catarina, Palhoça, SC, Brasil. 


\section{KEYWORDS}

- Diagnosis.

- Thought.

- Students.

- Medical Education.
ABSTRACT

Introduction: Clinical reasoning strategies (CR) employ hypothetical-deductive and inductive models as their theoretical basis. The first is based on the generation of hypotheses derived from a knowledge of pathologies and the second on a generalization derived from data on the case or an identification of a pattern. Doctors' or students' thoughts may be evaluated by the "think aloud" technique (TAT). Objectives: To identify the CR strategies used by medical students at the end of the basic cycle, as well as the organization and contents of their knowledge, analyzing an internal medicine prototype clinical case by means of the TAT. Method: A qualitative study was conducted on undergraduate medical students at the end of the basic cycle in a Brazilian university in 2014. The theory of prototypes served as the basis for building the clinical case, based on 41 students' perceptions of signs, symptoms, syndromes, and diseases typical of internal medicine. The TAT was individually applied to 30 randomly selected students in the original sample, in order to obtain an audio record of the verbalization of their reasoning processes in light of the case presented. A transcript of the speeches allowed us to evaluate the texts by means of content analysis, and to categorize the reasoning techniques employed. Semantic axes were also identified and subsequently categorized into six classes: symptoms, signs, syndromes, diseases, factual data, and processes. Results: A total of 105 diagnostic hypotheses were created, in which 12 different types were identified as primary and 12 as secondary, with a mean of 3.5 principal hypotheses per student. The most commonly used reasoning style for developing the PDH was scheme-inductive $(S I)=42.3 \%$, followed by pattern recognition $(P R)=21.2 \%$, mixed SI (15.4\%), mixed PR (10.6\%), and hypothetic-deductive (10.6\%). As for knowledge organization and content, a mean of 12.9 semantic axes was recorded per student, with 20.9 interpretation processes per student and 6.8 combination processes per student. Conclusions: The inductive reasoning strategy is the most commonly used for developing PDHs among medical students at the end of the basic cycle. Students revealed a solid semantic network and skills in interpretation processes; however their combined abilities were limited when compared to those of experienced doctors.

\section{INTRODUCTION}

The current medical practice is based on clinical history and physical examination, laboratory tests and imaging exams ${ }^{1}$. Despite technological advances ${ }^{2}$, a well-conducted clinical history taking is still essential in making the diagnosis. The cognitive process of clinical reasoning starts from the effect towards the cause, as it originates in the signs and symptoms presented in the clinical history to form the diagnostic hypotheses ${ }^{3}$. Since the 1970's, a field of research opened in this area, which is based on the hypothetic-deductive ${ }^{2}$ theoretical model and on inductive reasoning ${ }^{4}$.

When applying the deductive logic to solve a clinical case $^{3}$, the doctor processes the signs and symptoms presented by the patient using the knowledge of certain diseases to generate diagnostic hypotheses ${ }^{2}$. These can then be used as a guide to selectively obtain new data that support these hypotheses ${ }^{5}$.

The inductive reasoning is based on generalizations that arise from basic data, without such information having been interpreted or combined ${ }^{6}$ by pattern recognition or a scheme-inductive process. In the first model, new cases are confronted with examples stored in the doctor's memory, allowing the resolution by recognizing the new cases as being similar or identical to previous histories ${ }^{6}$. In the second model, reasoning is linear, with only one hypothesis in mind $^{7}$, but follows a ramified path, in which certain findings exclude or induce a hypothesis or a particular group of them.

To assess the doctor's reasoning, there are techniques such as "concept mapping" ${ }^{\prime \prime}$ and the "think aloud"9 protocol, the latter being the most widely used. In it, the verbal data obtained can be used to study the cognitive process under specific and controlled situations ${ }^{9}$. With proper guidance, a survey with this technique can be performed without previous training because the verbal data are consistent with the cognitive process and the ability to usual verbalization. Using this data is possible to assimilate the process of generation or formulation of diagnostic hypotheses, as well as the knowledge organization and content $\mathrm{t}^{10,11}$, by the analysis of semantic axes and interpretation processes (abstraction) and combination (association).

Understanding the solving of a medical problem from the thought of an experienced or novice professional, and even of a student, can optimize and improve the teaching of clinical reasoning. 
The undergraduate program of medicine in a public university in southern Brazil, at the end of the second year has provided contents in physiology, anatomy, medical semiology, and basic medical reasoning. This study aimed at identifying the clinical reasoning strategies and the organization and content of knowledge of these students, when solving a clinical prototype case in internal medicine, by using the "think aloud" technique.

\section{METHOD}

This is a qualitative study based on the method described by Stamm ${ }^{12}$. In 2014, 41 students of a public university in southern Brazil, at the end of the second year of the undergraduate program of medicine - basic cycle - were invited to participate in the survey. The contents of the basic cycle focus on medical semiology, basic medical reasoning, physiology, anatomy, histology, cell biology, biochemistry, among others.

In the first stage of the research, taking into account that the knowledge of participants is heterogeneous, regardless of the fact that they are in the same state of the program, it was suggested the development of a group of signs, symptoms, syndromes and diseases prototypes in internal medicine, which allowed selecting a typical and real clinical case from the most cited elements in each category.

In the second stage, we randomly selected 30 participants of the original group. In a place and at a time previously established, each of the participants received a structured questionnaire to fill out in order to provide the research with their demographics and academic profile, as well as a tablet with a clinical case on the screen. After completing the questionnaire, the student was advised in writing and verbally about the "think aloud" technique, proposed by Ericsson and Simon in the 1980's ', which consists in verbalizing the reasoning process together with reading of the case presented. The researcher remained onsite, although out of the student's field of view, interfering only when they remained silent for more than 10 seconds, at which time the researcher encouraged the student with the sentence "keep thinking out loud." The speeches were recorded on the same tablet and were later transcribed verbatim.

In the third and final stage, the content analysis technique proposed by Bardin ${ }^{13}$ was applied to the texts obtained from the verbalization of each participant. A chart was prepared with the transcribed text in the first column, the encoding in the second column [obtain (signs or symptoms or additional medical data), process (interpret and/or combine) basic data, generate (syndromes or diseases), and test (confirm or refine or refute) diagnostic hypotheses in the deductive model; formulate (syndromes or diseases) and test (verify or refute) in the inductive model], and the third column, the categories within the clinical reasoning strategies: hypothetic-deductive (HD) or inductive - by pattern recognition (PR) or scheme-inductive (SI) - or mixed (RP and HD or SI and HD).

The diagnostic hypotheses were classified as "principal primary", "principal secondary", or "secondary", being related to each reasoning strategy in which they were developed. At the end of the chart, they were listed and grouped in a syndrome or standard condition (e.g., "bronchopneumonia" was considered a development of the standard condition "pneumonia"). The number of context and analysis units, cut as standardized by analytical technique ${ }^{12}$, and the number of semantic axes were also displayed. These are usually represented by binary oppositions (e.g. "acute vs. chronic"), and were considered in relation to diseases, syndromes, signs, symptoms, additional medical data, and processes. In the end of the chart, the amount of interpretation processes (abstraction), combination (association) and the matching of both (interpretation plus combination) were also shown.

The content analysis of the first two transcriptions was approved by an expert, what allowed continuing the analysis. By the end of this process, the same expert and a new invited one reviewed and approved other five randomly chosen analysis from the 30. After that validation, the results of analysis were reassessed again.

\section{RESULTS}

In 2014, prototypes in internal medicine (signs, symptoms, syndromes, and diseases) were developed by 41 students who completed the basic cycle of the undergraduate program in medicine. In the perception of the participants, 45 signs, 35 symptoms, 36 syndromes, and 52 diseases were listed (see the four most cited prototypes in each category in Table 1).

Of the original number, 30 participants were selected by lot for the next phase - application of a questionnaire and resolution of a case in internal medicine - by application of the "think aloud" technique. The demographics and profile of these students (Table 2) showed a slight prevalence of females (56.6\%), with most of them between 18 and 25 years (83\%) and single (96.6\%). More than half (60\%) dedicates $4-10$ hours of study per week and considers their dedication to the program good $(50 \%)$ or regular (50\%). Most (90\%) took part in some extracurricular activity, of which $53 \%$ related to internal medicine (IM); $40 \%$ did an internship in this specialty, and $43 \%$ have one or more undergraduate courses in another area. The 30 audio recordings totaled $242^{\prime}$ and $9^{\prime \prime}$, averaging $8^{\prime}$ and $4^{\prime \prime}$ per student. 
TABLE 1

Prototypes in internal medicine in the perception of medical students of the basic cycle

\begin{tabular}{|c|c|c|c|}
\hline Category & Main prototypes & Total & $\%$ \\
\hline \multirow[t]{4}{*}{ Signs } & Fever & 24 & 58.5 \\
\hline & Edema & 23 & 56.0 \\
\hline & Jaundice & 21 & 51.2 \\
\hline & Cyanosis & 19 & 46.3 \\
\hline \multirow[t]{5}{*}{ Symptoms } & Dyspnea & 32 & 78.0 \\
\hline & Headache & 27 & 65.8 \\
\hline & Chest pain & 14 & 34.1 \\
\hline & Cough & 14 & 34.1 \\
\hline & Asthenia & 14 & 34.1 \\
\hline \multirow[t]{4}{*}{ Syndromes } & Anemic syndrome & 28 & 68.2 \\
\hline & Acute coronary syndrome & 23 & 56.0 \\
\hline & COPD & 20 & 48.7 \\
\hline & Febrile syndrome & 19 & 46.3 \\
\hline \multirow[t]{4}{*}{ Diseases } & AMI & 15 & 36.5 \\
\hline & $\mathrm{CHF}$ & 15 & 36.5 \\
\hline & Asthma & 15 & 36.5 \\
\hline & Hypertension & 14 & 34.1 \\
\hline
\end{tabular}

${ }^{*} n=41$ participants. $\mathrm{COPD}=$ chronic obstructive pulmonary disease $;$ AMI $=$ acute myocardial infarction; $\mathrm{CHF}=$ congestive heart failure.

Source: Clinical reasoning of medical students, $2014-$ UFSC

The content analysis of the verbalized data showed 627 interpretation processes (IP), 205 combination processes (CP), and 117 mixed processes in this amount, averaging $20.9 \mathrm{IP} /$ student and $6.83 \mathrm{CP} /$ student. Sixty-three different semantic axes were identified in a total of 387 axes (mean of 12.9 axes/ student), related to six categories: symptoms, signs, syndromes, diseases, additional medical data, and processes. The category with the largest number of different axes was that of signs, having been reported 21 times (33\%), but no formation of axes was reported in syndromes.

One hundred and five principal diagnostic hypotheses (PDH) were identified, in which 12 different types were identified as primary and 12 as secondary, with a mean of 3.5 principal hypotheses per student. The most cited primary PDHs were in descending order: upper respiratory infection (URI), COPD (or exacerbation of COPD), and pneumonia. As for the most frequent secondary PDHs, we had in descending order: COPD, pneumonia, and upper respiratory infection. Twenty-seven secondary diagnostic hypotheses (SDH) were prepared, with 11 different types and a mean of 0.90 hypotheses per student (heart failure, and deep vein thrombosis were the most frequent).

Regarding the clinical reasoning strategies in preparing the PDHs, a prevalence of the inductive model was observed, with a higher rate of the scheme-inductive (SI) model in relation to the pattern recognition (PR), with $42.3 \%$ and $21.2 \%$, respectively. The third most used strategy was the mixed SI $(15.4 \%)$, followed by mixed PR and hypothetic-deductive (HD), at a rate of $10.6 \%$ each (Table 3, Figure 1).

When preparing the secondary hypotheses (Table 4, Figure 2) a prevalence of the inductive strategy, represented in $62 \%$ by S-I and in $10 \%$ by P-R, followed by mixed S-I (17\%) and H-D (11\%) was observed.

TABle 2

Student demographics and profile

\begin{tabular}{|c|c|c|c|c|c|}
\hline \multirow[t]{2}{*}{ Parameter } & \multicolumn{5}{|c|}{ Answers } \\
\hline & \multicolumn{2}{|c|}{ Male: $43.3 \%$} & \multicolumn{3}{|c|}{ Female: $56.6 \%$} \\
\hline Age & \multicolumn{2}{|c|}{$\begin{array}{c}18-25 \text { years } \\
83.3 \%\end{array}$} & $\begin{array}{c}26-30 \text { years } \\
13.3 \%\end{array}$ & \multicolumn{2}{|c|}{$\begin{array}{c}>31 \text { years } \\
3.3 \%\end{array}$} \\
\hline Marital status & $\begin{array}{l}\text { Single } \\
96.6 \%\end{array}$ & $\begin{array}{c}\text { Married } \\
0 \%\end{array}$ & $\begin{array}{c}\text { Divorced } \\
3.3 \%\end{array}$ & $\begin{array}{c}\text { Widowed } \\
0 \%\end{array}$ & $\begin{array}{c}\text { Other } \\
0 \%\end{array}$ \\
\hline Hours of study/week & \multicolumn{2}{|c|}{$\begin{array}{c}1-3 \text { hours } \\
20 \%\end{array}$} & $\begin{array}{l}\text { 4-10 hours } \\
60 \%\end{array}$ & \multicolumn{2}{|c|}{$\begin{array}{c}>10 \text { hours } \\
20 \%\end{array}$} \\
\hline Dedication (subjective analysis) & $\begin{array}{l}\text { Low } \\
0 \%\end{array}$ & $\begin{array}{c}\text { Regular } \\
50 \%\end{array}$ & $\begin{array}{c}\text { Good } \\
50 \%\end{array}$ & $\begin{array}{c}\text { Excellent } \\
0 \%\end{array}$ & \\
\hline Extracurricular activity* & \multicolumn{2}{|c|}{ Yes: $90 \%$} & \multicolumn{3}{|c|}{ No: $10 \%$} \\
\hline Related to IM & \multicolumn{2}{|c|}{ Yes: $53.3 \%$} & \multicolumn{3}{|c|}{ No: $46.6 \%$} \\
\hline Internship in IM & \multicolumn{2}{|c|}{ Yes: $40 \%$} & \multicolumn{3}{|c|}{ No: $60 \%$} \\
\hline Other undergraduate degree & & & $\begin{array}{c}\text { Two or more } \\
9.9 \%\end{array}$ & & \\
\hline
\end{tabular}

$n=30$ participants; IM = Internal Medicine; *Extracurricular activity: academic league or other extension or research project

Source: Clinical reasoning of medical students, 2014 - UFSC 


\begin{tabular}{|c|c|c|c|c|c|c|}
\hline \multicolumn{7}{|c|}{$\begin{array}{l}\text { TAвLE } 3 \\
\text { evelopme } \\
\text { linical ca }\end{array}$} \\
\hline \multicolumn{7}{|c|}{ Clinical reasoning strategies } \\
\hline hypotheses & H-D & S-I & P-R & Mixed S-I & Mixed P-R & Number of strategies \\
\hline Primary & $11(14.6 \%)$ & $30(40 \%)$ & $17(22.6 \%)$ & $9(12 \%)$ & $8(10.6 \%)$ & $75(100 \%)$ \\
\hline Secondary & $0(0 \%)$ & $14(48.2 \%)$ & $5(17.2 \%)$ & $7(24.1 \%)$ & $3(10.3 \%)$ & $29(100 \%)$ \\
\hline Total & $11(10.6 \%)$ & $44(42.3 \%)$ & $22(21.2 \%)$ & $16(15.4 \%)$ & $11(10.6 \%)$ & $104(100 \%)$ \\
\hline
\end{tabular}

Legend: H-D (hypothetic-deductive); S-I (scheme-inductive); P-R (pattern recognition); Mixed S-I (beginning S-I + HD); Mixed PR (beginning P-R + H-D). Source: Clinical reasoning of medical students, $2014-U F S C$

\begin{tabular}{|c|c|c|c|c|c|c|}
\hline \multirow{3}{*}{$\begin{array}{l}\text { Diagnostic } \\
\text { hypotheses }\end{array}$} & \multicolumn{6}{|c|}{$\begin{array}{l}\text { Clinical reasoning strategies in the development of secondary diagnostic hypotheses } \\
\text { in solving a prototype clinical case in internal medicine }\end{array}$} \\
\hline & \multicolumn{5}{|c|}{ Clinical reasoning strategies } & \multirow{2}{*}{$\begin{array}{l}\text { Number of } \\
\text { strategies }\end{array}$} \\
\hline & H-D & S-I & P-R & Mixed S-I & Mixed P-R & \\
\hline Secondary & $3(10.3 \%)$ & $18(62 \%)$ & $3(10.3 \%)$ & $5(17.2 \%)$ & $0(0 \%)$ & $29(100 \%)$ \\
\hline
\end{tabular}

Legend: H-D (hypothetic-deductive); S-I (scheme-inductive); P-R (pattern recognition); Mixed S-I (beginning S-I + H-D); Mixed PR (beginning P-R + H-D). Source: Clinical reasoning of medical students, $2014-$ UFSC

\section{DISCUSSION}

Medical students at the end of basic theoretical cycle mainly used inductive strategy when in the face of a prototype clinical case in internal medicine, both when preparing the PDHs (65.3\%) and the SDHs (72\%). These percentages increase to $89.1 \%$ and $89 \%$, respectively, when mixed strategies are considered, which are those hypotheses formulated initially by inductive reasoning, and subsequently improved, refuted, or confirmed by the deductive method. These findings are supported in the literatu$\mathrm{re}^{14,15}$, although there are few studies conducted with students.

The use of the inductive method among experienced physicians is well documented ${ }^{6,14,16}$, but the deductive strategy has been described as the most used among beginners, such as residents in internal medicine ${ }^{17}$. Pottier et al..$^{14}$ showed an increase in the use of the deductive over the inductive strategy when comparing the reasoning of students from the $3^{\text {rd }}$ and $5^{\text {th }}$ years, but they also identified a new increase in the inductive method amongst medical specialists.

By analyzing the transcripts obtained with the "aloud think" technique, it was revealed that students do not yet have a clear understanding of the symptoms found during the clinical examination, which served as experiment, which may explain in part the low rate of hypothetic-deductive reasoning use.

Although a student might prepare a lower number of diagnostic hypotheses than an experienced doctor, these stu- dents have demonstrated a solid semantic network, since they showed a mean of semantic axes per participant similar to that of a survey of medical teachers, in which the same method had been applied ${ }^{12}$.

Considering the semantic network and a higher mean of abstraction processes (interpretation) than that found in Stamm's study ${ }^{12}$, it can be inferred that the undergraduate students show knowledge organization, but a not so deep thought due to a lower combination (association) skill.

The "think aloud" technique has limitations. When verbalizing each and any thought, the individual can change their reasoning, since speaking out loudly requires cognitive resources $^{18}$ and might drive to distraction ${ }^{19}$. The disclosure of thoughts can also cause embarrassment and, thus, inhibit some verbalizations.

Regardless of these limitations, the findings of this study reinforce the importance of inductive reasoning for students, but do not necessarily imply that medical education should focus only on non-analytical reasoning, because although the latter is useful for solving routine cases, it is by employing the analytical method that complex or unique cases are solved ${ }^{20}$.

Some authors argue that, to be able to learn medical thinking, the student needs to have a well-established pathophysiological basis ${ }^{21}$. However, Kassirer et al. ${ }^{21}$ believe that, using selected clinical cases, it is possible to start teaching this 
process already in the first year of the medical course, because "[...] clinical cognition requires a flexible cast of mind, a power of observation, and a willingness to question, to learn from others, and to compare notes." (Kassirer et al., 2010, p. 1121). In other words, the mind of the beginner may be an advantage on learning clinical reasoning because it is still flexible.

\section{CONCLUSIONS}

The strategy of inductive clinical reasoning is prevalent among medical students at the end of the basic cycle, with the scheme-inductive category prevailing in the formulation of principal and secondary diagnostic hypotheses.

The students showed a solid semantic network and good skills in the abstraction processes - reflecting knowledge organization - but a not very deep thought due to low association skills compared to experienced doctors.

\section{REFERENCES}

1. Bickley LS. LWW, editor. Philadelphia: Wolters Kluwer; 2012.

2. Elstein AS, Shulman LS, Sprafka SA. Medical Problem Solving: An Analysis of Clinical Reasoning. Bulletin of the New York Academy of Medicine. 1978:886-7.

3. López M. O processo diagnóstico nas decisões clínicas: Ciência - Arte - Ética. Rio de Janeiro: Livraria e Editora Revinter Ltda; 2001.

4. Bacon F. Novum organum ou verdadeiras indicações acerca da interpretação da natureza. 2a ed. São Paulo: Abril Cultural; 1979.

5. Elstein AS, Schwarz A. Clinical problem solving and diagnostic decision making: selective review of the cognitive literature. British Medical Journal. 2002;324:729-32.

6. Coderre S, Mandin H, Harasym PH, Fick GH. Diagnostic reasoning strategies and diagnostic success. Medical Education. 2003;37:695-703.

7. Norman G, Young M, Brooks L. Non-analytical models of clinical reasoning: the role of experience. Medical Education. 2007:1140-5.

8. Charlin B, Lubarsky S, Millette B, Crevier F, Audétat MC. Clinical reasoning processes: unravelling complexity through graphical representation. Medical Education. 2012; 46(5):454-63.

9. Ericsson KA, Simon HA. Protocol Analysis: Verbal reports as data. 2nd, editor. Boston: MIT Press; 1993.

10. Bordage G. Elaborated knowledge: a key to successful diagnostic thinking. Academic Medicine. 1994:883-5.

11. Bordage G. Prototypes and semantic qualifiers: from past to present. Medical Education. 2007;41:1117-21.

12. Stamm AMNdF, Fialho FAP. Raciocínio Clínico do Diagnóstico Médico. Florianópolis: UFSC; 2007.
13. Bardin L. Análise de conteúdo. Lisboa: LDA; 1977. 226 p.

14. Pottier P, Hardouin J-B, Hodges BD, Pistorius M-A, Connault J, Durant $C$, et al. Exploring how students think: a new method combining think-aloud and concept mapping protocols. Medical Education. 2010:926-35.

15. Fornaziero CC, Gordan PA, Garanhani ML. Clinical Reasoning of Medical Students in a Public University in Brazil. Revista Brasileira de Educação Médica. 2012:463-9.

16. Mclaughlin K, Heemskerk L, Herman R, Ainslie M, Rikers $\mathrm{R}$, Schmidt $\mathrm{H}$. Initial diagnostic hypotheses bias analytic information processing in non-visual domains. Medical Education. 2008:496-502.

17. Heemskerk L, Norman G, Chou S, Mintz M, Mandin H, McLaughlin K. The effect of question format and task difficulty on reasoning strategies and diagnostic performance in internal medicine residents. Advances in Health Sciences Education. 2008:453-62.

18. Bannert M, Mengelkamp C. Assessment of metacognitive skills by means of instruction to think aloud and reflect when prompted. Does the verbalisation method affect learning? Metacognition Learning. 2008;3:39-58.

19. Young KA. Direct from the source: the value of 'think-aloud' data in understanding learning. Journal of Educational Enquiry. 2005;6(1):19-33.

20. Mamede S, Schmidt HG, Penaforte JC. Effects of reflective practice on the accuracy of medical diagnoses. Medical Education. 2008:468-75.

21. Kassirer JP. Teaching Clinical Reasoning: Case-Based and Coached. Academic Medicine. 2010:1118-24.

\section{CONTRIBUIÇÃO DOS AUTORES}

Djon Machado Lopes colaborou no desenvolvimento do projeto, bem como na coleta de dados. Bruna Morais Barbosa contribuiu na revisão bibliográfica e na revisão das análises das transcrições. Ana Maria Nunes de Faria Stamm elaborou o método no qual o artigo baseou-se e orientou toda a pesquisa.

\section{CONFLITO DE INTERESSES}

Não há conflitos de interesses de nenhuma parte dos envolvidos.

\section{ENDEREÇO PARA CORRESPONDÊNCIA}

Gustavo Henrique Bregagnollo

Universidade Federal de Santa Catarina - Clínica Médica

Rua Eng. Agronômico Andrei Cristian Ferreira, s/n ${ }^{\circ}$

Trindade - Florianópolis - CEP 88040-900 - SC

E-mail: gustavo.hbrg@gmail.com; djonmachado@gmail.com; brunamorais_ipo@hotmail.com; anamnfstamm@gmail.com 